\title{
IMMUNOGLOBULIN Fc RECEPTORS IN CLINICAL STRAINS OF Staphylococcus aureus DO NOT CONFER RESISTANCE TO PHAGOCYTOSIS IN AN IN VITRO ASSAY
}

\author{
Benito VEGA (1), Jorge D. GARCIA $(1,2)$ \& Francisco HERNÁNDEZ $(1,3)$
}

\begin{abstract}
SUMMARY
Staphylococcus aureus binds Immunoglobulin $\mathrm{G}(\mathrm{IgG})$ on its external surface due to the presence of specific receptors for the Fc domain of this immunoglobulin. This mechanism represents a kind of camouflage against phagocytic cells. In order to confirm that possibility an in vitro evaluation of the phagocytic activity of leukocytes polymorpho-nuclear (PMN) against strains of Staphylococcus aureus was done, comparing 18 strains isolated from clinical samples and 16 from healthy individuals. The presence of Fc receptors was evaluated by haemagglutination (HA) with erythrocytes group A after incubation of the strains with IgG anti blood group A. Phagocytosis of $S$. aureus was carried out by mixing live bacteria with a suspension of human PMN and incubating at $37^{\circ} \mathrm{C}$ for $1 \mathrm{~h}$; survivors were counted as colony forming units by plating. The strains from clinical specimens showed higher HA than those from healthy individuals $(\mathrm{p}=0.01)$; but the former were killed more efficiently than the latter $(80-90 \%$ and $40 \%$, respectively). It is may be possible that $S$. aureus showed different behavior in vivo, where could express other virulence factors to prevent the action of phagocytes.
\end{abstract}

KEYWORDS: Staphylococcus aureus; Fc receptors and phagocytosis; Phagocytic evasion; Polymorphonuclear leukocytes; Haemagglutination.

\section{INTRODUCTION}

One of the most important non-specific immune reactions of a host is the activity of phagocytes, which internalize bacteria to destroy them. It has been proposed that the presence of protein A on the cell wall of $S$. aureus would cause them to be covered with host immunoglobulins (Ig) bound to the bacterial cell through their Fc domains ${ }^{6}$. Due to its affinity to Ig Protein A has been called "the Fc receptor". Bacteria covered with host Ig would not be recognized by phagocytic cells, thus preventing their activation ${ }^{1,5,6}$.

Fc receptors on bacterial surfaces can be estimated using an assay developed by YAMADA et al. (1991) ${ }^{11}$ and modified by HERNÁNDEZ \& RIVERA (1998) ${ }^{3}$. Bacterial cells are incubated with IgG specific against group A red-blood cells. Fc-receptors on the surface of the bacterial cells bind IgG through their Fc domain, allowing IgG molecules to bind to group A red-blood cells, resulting in a haemagglutination reaction (HA). The titers of HA obtained in this manner provide indirect measurements of FC receptors on bacterial surfaces.

The overall aim of this study was to evaluate whether the presence of Fc receptors on the surface of $S$. aureus protects bacteria against phagocytosis and killing in an in vitro assay of phagocytosis.

\section{MATERIALS AND METHODS}

Bacteria: A total of thirty-four strains of $S$. aureus were evaluated, 18 of them were isolated from abscesses or blood from patients at San Juan de Dios Hospital, San José, Costa Rica. The other 16 strains were from the skin of healthy high-school students. All strains were identified using a BACTEC 9050 (Becton Dickinson Diagnostic Instrument System).

Haemagglutination (HA): Bacteria were coated with human monoclonal anti (blood group) A IgG, by mixing a bacterial suspension (density equivalent to tube 1 of a MacFarland nephelometer $-3 \times 10^{8}$ cells $/ \mathrm{mL}$ ), with the antibody and incubating $30 \mathrm{~min}$ at $37{ }^{\circ} \mathrm{C}$. The bacterial cells were washed 3 times and aliquotes of $50 \mu \mathrm{L}$ of this suspension were placed in $\mathrm{U}$ shaped microtiter wells, then $50 \mu \mathrm{L}$ of a $5 \%$ suspension of blood A erythrocytes were added and the plate was incubated at $37^{\circ} \mathrm{C}$ for $30 \mathrm{~min}$ and placed at $4{ }^{\circ} \mathrm{C}$. The HA was evaluated at 4,8 and $24 \mathrm{~h}$. To estimate the density of IgG-receptors on the surface of bacteria, serial two-fold dilutions of the antibody were made and the process was followed as above described to obtain the end point for the $\mathrm{HA}^{3,11}$.

Phagocytosis assay: The method described by GADEBERG et al $^{2}$ was used. Briefly, $500 \mu \mathrm{L}$ of polymorphonuclear (PMN) leukocytes (5

(1) Facultad de Microbiología, Universidad de Costa Rica, San José, Costa Rica

(2) Escuela de Medicina, Universidad de Costa Rica, San José, Costa Rica.

(3) Unidad de Microscopia Electrónica, Universidad de Costa Rica, San José, Costa Rica.

Correspondence to: Dr. Francisco Hernández, Unidad de Microscopia Electrónica, Universidad de Costa Rica, San José, Costa Rica. 


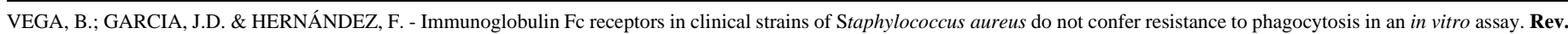
Inst. Med. trop. S. Paulo, 41 (3): 143-145, 1999.

x $10^{6}$ cells $/ \mathrm{mL}$ ) suspended in phosphate buffered saline with $1 \mathrm{mM}$ calcium and $5 \mathrm{mM}$ glucose (PBS-Ca-glucose), concentrated according KALMAR et al. ${ }^{4}$ were placed in Ependorff tubes. Each tube received a mixture of $300 \mu \mathrm{L}$ PBS-Ca-glucose, $100 \mu \mathrm{L}$ of serum from a healthy individual, and $100 \mu \mathrm{L}$ of a suspension of each bacterial strain (density equivalent to the tube number 2 of MacFarland nephelometer $-6 \times 10^{8}$ cells/mL) incubation followed for $1 \mathrm{~h}$ at $37^{\circ} \mathrm{C}$, with mixing of contents every $10 \mathrm{~min}$.

At the same time the phagocytosis assay was run, another control tube for each strain was prepared without PMNs to evaluate bacterial survival in the presence of serum. Into these tubes were added $100 \mu \mathrm{L}$ of serum, $100 \mu \mathrm{L}$ of the bacterial suspension, and $800 \mu \mathrm{L}$ of PBS-Caglucose, and were incubated at $37{ }^{\circ} \mathrm{C}$. At time 0 and after $60 \mathrm{~min}$ of incubation, aliquots were taken and then serially diluted to $10^{-7}$, plated onto tripticase soy agar plates and incubated for $24 \mathrm{~h}$ at $35^{\circ} \mathrm{C}$, after which surviving bacteria (colony formed units, or CFU) were counted.

Lysostaphine assay: Four strains of $S$. aureus, two isolated from clinical samples and another two from healthy individuals were subjected at the same process described above, with the exception that after $45 \mathrm{~min}$ into incubation period, $15 \mu \mathrm{L}$ of lysostaphine (Sigma 0761) in PBS-Ca-glucose $(25 \mathrm{U} / \mathrm{mL})$ were added to lyse all extracellular bacteria.

Microscopic count of PMN with phagocytosed bacteria: From each tube used for both, the phagocytosis assay count of CFU and lysostaphine, smears were prepared and stained with Leishman solution to count the number of PMN cells either with associated or internalized bacteria.

\section{RESULTS}

S. aureus strains isolated from clinical specimens showed higher haemagglutination titers than those isolated from healthy individuals $\left(\mathrm{X}^{2}=5.81, \mathrm{p}=0.01\right)$. These results indicate that the former possess more surface $\mathrm{Fc}$ receptors than those isolated from healthy individuals (Table $1)$.

Surprisingly, when clinical strains were challenged with PMN leukocytes in a phagocytosis assay, bacterial killing was above $90 \%$, whereas the range of bacterial killing was 40 to $50 \%$ in strains isolated from healthy individuals (Table 2).

Light microscopy assessment of phagocytosis at $60 \mathrm{~min}$ showed that control strains were not as frequently associated with leukocytes (40\%) as clinical isolates (80-90\%). Phagocytosis was assessed also in prepa-

Table 1

Haemagglutination of Staphylococcus aureus incubated with human IgG antiA followed by group-A-erythrocytes

\begin{tabular}{lcc}
\hline Bacterial source & Haemagglutination & Titer \\
\cline { 2 - 3 } & $\leq 1: 2$ & $\geq 1: 8$ \\
\hline Healthy individuals & 9 & 7 \\
Clinical samples & 3 & 15 \\
\hline
\end{tabular}

$\mathrm{X}^{2}=5.81, \mathrm{p}=0.01$.
Table 2

Bacterial killing after phagocytosis of Staphylococcus aureus

\begin{tabular}{lccc}
\hline Strain origin & $\begin{array}{c}\text { Mortality } \\
<50 \%\end{array}$ & $\begin{array}{c}\text { Mortality } \\
>50 \%\end{array}$ & Total \\
\hline Healthy individuals & 15 & 1 & 16 \\
Clinical samples & 1 & 17 & 18 \\
\hline
\end{tabular}

$\mathrm{X}^{2}=26.45, \mathrm{p}<0.0001$

rations to which lysostaphin was added after 45 min to lyse all but intracellular bacteria in order to avoid mistaking externally associated bacteria with ingested ones. We thus corroborated that only $40 \%$ from non-clinical strains were killed, in comparison with $80-90 \%$ of bacteria from clinical isolates. These data support the finding that the latter are phagocytosed and killed to a greater extent.

\section{DISCUSSION}

In previous work, we labeled $\mathrm{Ig}$ attached to $\mathrm{Fc}$ receptors on the bacterial surface of $S$. aureus with anti-human-IgG conjugated with colloidal gold particles, showing that strains with high HA titers exhibited higher number of surface gold particles, homogeneously distributed on bacterial surface, than strains with low HA titers. In these labeling experiments gold particles represent the distribution of Fc receptors ${ }^{3}$. Also, if the IgG attached on the bacteria by their Fc domains represent a kind of camouflage, we expected that strains with high concentration of Fc receptors could exhibit some antiphagocytic activity or survived to the phagocytosis more than strains with fewer Fc receptors. Nevertheless, our findings are unexpected and taken to indicate that the presence of Fc receptor in clinical $S$. aureus specimens does not offer protection against phagocytosis, at least in our in vitro assay.

This means the possible masking effect of serum $\operatorname{IgG}$ bound to the bacterial surface was not enough to prevent adherence and ingestion by phagocytes, and it somehow resulted in increased association and phagocytosis of $S$. aureus. It may be possible for this agent to behave differently in vivo, where expression of other virulence factors may come into play, such as coagulase production. Alternatively, host factors such as interleukins could increase the bactericidal activity of $\mathrm{PMN}^{8-10}$.

This data showed that under our experimental conditions, $S$. aureus strains which exhibited more $F c$ receptors were phagocytosed and killed in higher proportion than strains from healthy persons, which showed fewer Fc on their surface.

\section{RESUMEN}

\section{Los receptores Fc para inmunoglobulinas en cepas clinicas de Staphylococcus aureus no confieren resistencia a la fagocitosis in vitro}

Staphylococcus aureus liga inmunoglobulinas G (IgG) a su superficie externa debido a la presencia de receptores para el dominio Fc de esas inmunoglobulinas. Este mecanismo representa una clase de camuflage contra células fagocíticas. Para confirmar tal posibilidad se realizó una evaluación in vitro de la actividad fagocítica de leucocitos polimorfonucleares (PMN) contra cepas de Staphylococcus aureus, comparando 


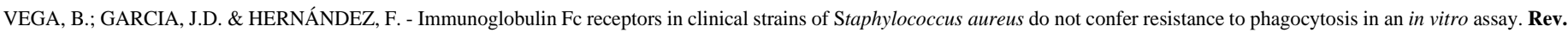
Inst. Med. trop. S. Paulo, 41 (3): 143-145, 1999.

18 cepas aisladas de casos clínicos y 16 de individuos sanos. La presencia de receptores fue evaluada por hemaglutinación (HA) con eritrocitos grupo A luego que las cepas fueron incubadas con IgG anti grupo sanguíneo A. La fagocitosis de $S$. aureus fue realizada mezclando células vivas con una suspensión de PMN e incubada a $37^{\circ} \mathrm{C}$ por una hora; las bacterias sobrevivientes fueron contadas como unidades formadoras de colonias por plateo. Las cepas provenientes de especímenes clínicos mostraron mayor HA que aquellas provenientes de individuos sanos ( $\mathrm{p}=0.01$ ); pero las primeras fueron eliminadas más eficientemente que las últimas (80-90\% y 40\%, respectivamente). Es posible que $S$. aureus muestre un comportamiento diferente in vivo, donde podría expresar otros factores de virulencia para prevenir la acción de los fagocitos.

\section{REFERENCES}

1. BENGUALID, V.; HATCHER, V.B.; DIAMOND, B.; BLUMBERG, E.A. \& LOWY, F.D. - Staphylococcus aureus infection of human endothelial cells potentiates Fc receptor expression. J. Immunol., 145: 4279-4283, 1990.

2. GADEBERG, O.V.; ORSKOV, I. \& RHODES, J.M.- Cytotoxic effect of an alpha hemolytic Escherichia coli strain of human blood monocytes and granulocytes in vitro. Infect. Immun., 41: 358-364, 1983.

3. HERNANDEZ, F. \& RIVERA, P. - Receptores Fc en cepas de Staphylococcus aureus. Rev. costarric. Cienc. med., 19: 45-51, 1998.
4. KALMAR, J.R.; ARNOLD, R.R.; WARBINGTON, M.L. \& GARDNER, M.K. - Superior leukocyte separation with a discontinuous one-step Ficoll-Hypaque gradient for the isolation of human neutrophils. J. immunol. Meth., 110: 275-281, 1988.

5. KLOOS, W. \& BANNERMAN, T. - Staphylococcus aureus and Micrococcus. In: MURRAY, P., ed. Manual of clinical Microbiology. Washington, American Society for Microbiology, 1995. p. 282-297.

6. LINDMARK, R.; THORÉN-TOLLING, K. \& SJÖQUIST, J. - Binding of immunoglobulins to protein A immunoglobulins levels in mammalian sera. J. immunol. Meth., 62: 1-13, 1983.

7. ODIERNO, L.; ZANDARIN, A.; FERRARI, M. et al. - Comparación de métodos de detección de cápsula de S. aureus. Rev. lat-amer. Microbiol., 37: 245-255, 1995.

8. SIMMS, H.H. \& DAMICO, R. - Studies on polymorphonuclear leukocyte bactericidal function: the role of exogenous cytokines. Shock, 7: 84-89, 1997.

9. SIMMS, H.H. \& DAMICO, R. - Studies on polymorphonuclear leukocyte bactericidal function. II. The role of oxidative stress. Shock, 7: 339-344, 1997.

10. SIMMS, H.H. \& DAMICO, R. - Studies on polymorphonuclear leukocyte bactericidal function. III. The role of extracellular matrix proteins. J. surg. Res., 72: 123-128, 1997.

11. YAMADA, S.; MATSUMO, A.; VEHIRA, K. \& SUDA, T. - Immunoelectron microscopy of Fc receptors on the surface of clinical isolates of Streptococci. J. electron Microsc. (Tokyo), 40: 176-180, 1991.

Received: 14 December 1998

Accepted: 29 March 1999 